\title{
頭蓋骨縫合早期癒合症の診断と治療一現状と課題一
}

赤井 卓也 ${ }^{1)}$ ，山下 昌信 ${ }^{2}$ ，飯塚 秀明 ${ }^{3)}$ ，黑田 敏 ${ }^{1)}$

1）富山大学医学部脳神経外科，2）金沢医科大学医学部形成外科，3）同 脳神経外科

\section{Diagnosis and Treatment of Craniosynostosis : Current Status and Prob- lems}

Takuya Akai, M.D., Ph.D. ${ }^{1)}$, Masanobu Yamashita, M.D., Ph.D. ${ }^{2)}$, Hideaki Iizuka, M.D., Ph.D. ${ }^{3)}$, and Satoshi Kuroda, M.D., Ph.D. ${ }^{1)}$

1) Department of Neurosurgery, School of Medicine, University of Toyama, 2) Department of Plastic and Reconstructive Surgery, School of Medicine, Kanazawa Medical University, 3) Department of Neurosurgery, School of Medicine, Kanazawa Medical University

Craniosynostosis with early closure of skull sutures is categorized either as simple or as syndromic if present with other congenital anomalies such as midface hypoplasia, syndactyly, or joint contractures. Some children have a single affected suture, whereas some have multiple affected sutures. Skull shape varies depending on the affected sutures and the treatment needs to be done in the period of skull growth, which depends on age and skull shape. No consensus has been established for treatment decisions. New less invasive treatment methods such as distraction osteogenesis and molding helmets have been developed, but unsolved problems continue to be present. Here we discuss chronological changes in treatment methods, current status and problems, treatment algorithms, and research strategies for pathophysiology and prevention.

(Received November 29, 2018; accepted December 25, 2018)

Key words : craniosynostosis, treatment, diagnosis

Jpn J Neurosurg（Tokyo）28: 197-204, 2019

\section{まえがき}

頭蓋骨縫合早期癒合症は，頭蓋骨縫合だけが早期癒合 する単純型と顔面骨早期癒合，指趾異常（合指趾，幅広 拇趾なぞ)，関節拘縮，長管骨癒合，眼瞼下垂などを伴う 症候群がある。罹患縫合が単一の場合, 複数の場合があ り，頭蓋形態も種々で多様性に富む疾患である，発育途 中の頭蓋骨を治療するため，年齢，頭蓋形態により手術 方法が異なり, 治療のコンセンサスは確立されていな い. 低侵襲に良好な頭蓋形態を得るための手術法は進歩
しているが，以下のような未解決の課題がある：(1)頭蓋 骨あるいは顔面骨手術の最適年齢と手術法，(2)診断遅延 回避の方策，(3)軽症三角頭蓋症例の手術適応，(4)手術後 の発達改善の有無，(5)表現型と遺伝子変異のミスマッ チ，(5)特定の縫合だけが早期癒合を起こす原因の解明と 予防への応用。

本論文では，頭蓋骨縫合早期癒合症治療の歴史的変 遷，現状と課題，治療戦略のアルゴリズム，今後の研究 について述べる. 

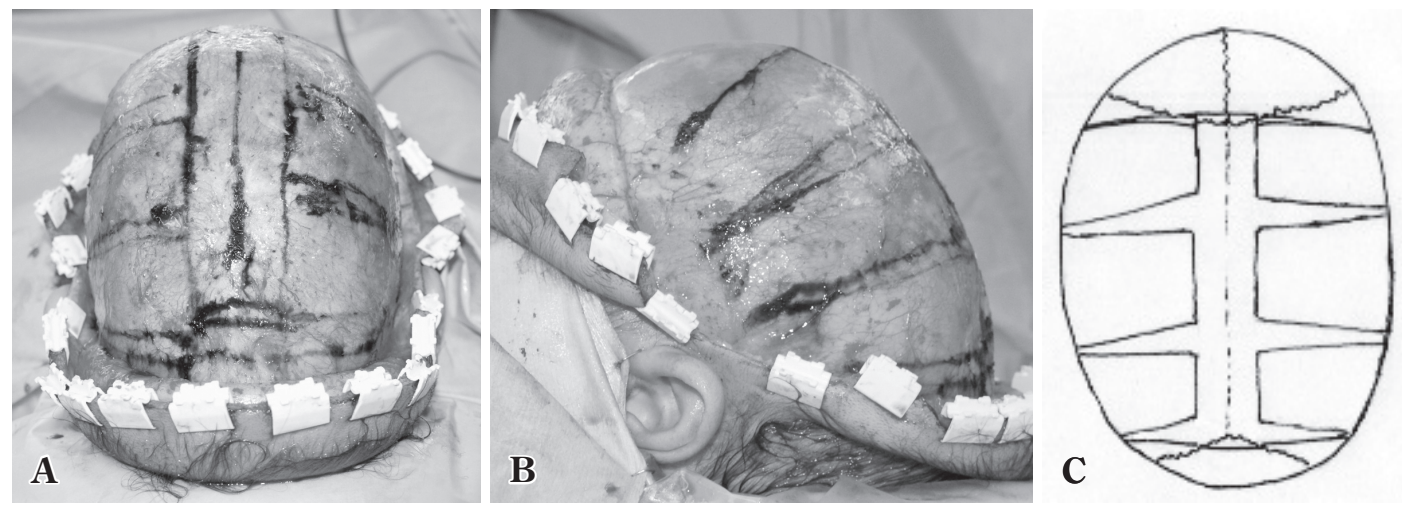

Fig. 1 Suturectomy for scaphocephaly

Top view and lateral view of the osteotomy line $(\mathbf{A}, \mathbf{B})$, and its schema $(\mathbf{C})$. The early fused sagittal suture and part of the coronal suture were removed. Triangular portions of parietal bones were also removed to correct the skull shape.

\section{治療法の変遷}

罹患縫合切除あるいは縫合切除十骨弁作成（floating） が行われていたが, 頭蓋冠拡大が不十分であり, 頭蓋拡 大手術が行われるようになった。しかし, 近年, 縫合切 除でも頭蓋形成ヘルメット (molding helmet) を併用する ことで良好な頭蓋形態が得られるようになった ${ }^{17) 18229)}$. 頭蓋拡大手術では, 頭蓋骨を外して拡大・固定する方法 （従来法）が開発され普及したが44)，1990年代に，下顎 骨の延長に骨延長器を用いる手術が開発され淿, その手 法を頭蓋骨に応用して頭蓋冠を拡大させる手術（骨延長 法 $)^{1441)}$ が登場した。骨延長法による前方, 側方拡大は, 日本，韓国からの報告が多いが，近年，骨延長法による 後方拡大は世界的に拡がりつつある ${ }^{34) 38)}$. 以下に各手術 法の詳細を述べる。

\section{1 罹患縫合切除}

早期癒合した縫合を切除し頭蓋骨成長の自由度を拡げ る (Fig. 1)。前頭骨の横径が狭いときは, 罹患縫合切除 に骨切りを追加し外側に若木骨折させることで拡大す る。しかし, 縫合切除だけでは, 罹患縫合が再癒合し良 好な頭蓋形態が得られないことが多い. よって, 縫合切 除後に包帯で固定，あるいは molding helmetを装着する. 頭蓋冠移動の必要がない矢状縫合早期癒合症がよい適応 であり, 頭蓋骨が軟らかい時期（3 カ月未満）の手術が 望ましいが，ヘルメットを用いることで 6 カ月ぐらいま では有効と報告されている ${ }^{19)}$. また，ヘルメット併用に より, 短頭蓋, 斜頭蓋, 三角頭蓋にも有効と報告されて いる2123). 一方, 舟状頭蓋に比べ, 短頭蓋, 三角頭蓋で は再手術が必要になることが多く, これらの病態には本
法の適応を慎重に考慮すべきとする意見もある ${ }^{11)}$, いず れにしても早期診断・治療が必須である.

\section{2 頭蓋拡大手術}

Fronto-orbital advancement (FOA) : 眼窩骨を含め, 前頭部を前方へ移動することで頭蓋前後径を拡大す $3^{31) 44}($ Fig. 2)，短頭蓋がよい適応である。従来法でも骨 延長法でも手術可能である。

Lateral expansion：頭蓋横径を拡大する (Fig. 3)。舟 状頭蓋に用い, 従来法, 骨延長法とも可能である.

Occipital expansion：FOA よりも大きな頭蓋冠容積 拡大が得られる ${ }^{34) 38}$, 後方拡大を先行して行うことで FOA が不要となることがある, 小脳扁桃下垂を伴ってい る症例では同時に大後頭孔減圧術が可能である, などの 利点がある (Fig. 4)。手術に際して, 横静脈洞を超えて 下方まで開頭することが望ましいが，出血に注意を要す る.

\section{3 従来法と骨延長法の比較 (Table 1)}

従来法は, 手術後の骨弁の後戻りがある, 皮膚の緊張 が強くなり創トラブルが起きやすい, 骨弁を外すため手 術侵襲が大きい（手術時間，出血）などの不利なところ がある。一方，細かな形態調整が可能，全治療期間が短 い（骨延長法では, 骨切りと延長器設置, シャフトカッ 卜, 延長器摘出と 3 回の手術を要し, 治療期間は約 3 力 月を要する), 治療費が骨延長法に比べ安い, 治療者の労 力が少ないなどの利点がある2). また, 骨延長法でも, より小さな骨片をつくり，それぞれにアンカーをつけ て，任意の方向に毫引することで，より繊細な頭蓋形態 を得る multi-directional cranial distraction osteogenesis 

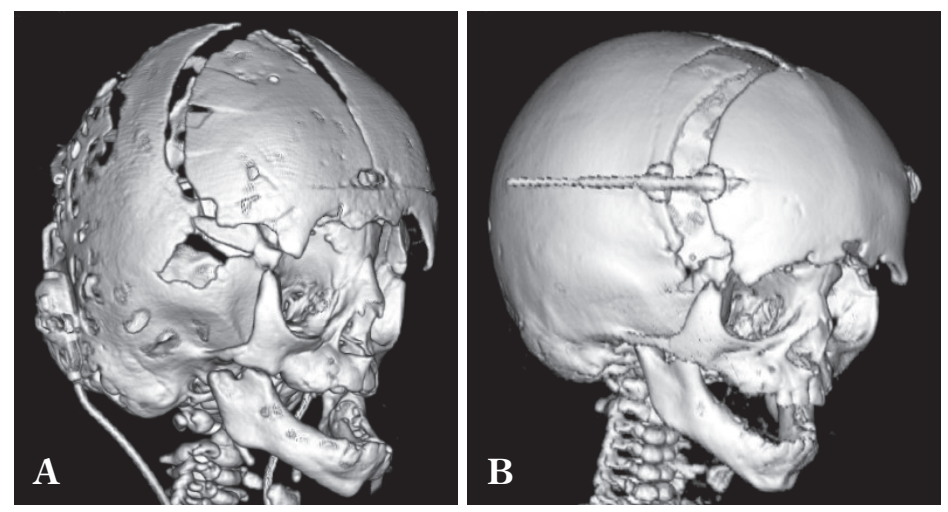

Fig. 2 Fronto-orbital advancement via conventional cranioplasty and distraction osteogenesis

The frontal bone flap and orbital bandeau were isolated and moved forward and fixed using absorbable plates (A). One piece frontal bone flap with orbital rim was isolated with minimal dissection of the dura mater, and distractors were placed. The bone flap was advanced forward to the scheduled distance every day (B).

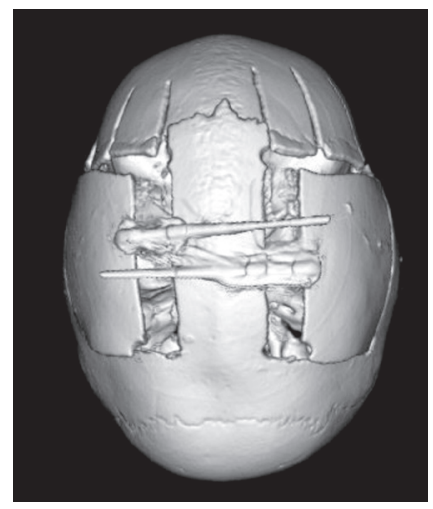

Fig. 3 Lateral expansion via distraction osteogenesis for scaphocephaly

Osteotomy was performed on the bilateral frontal and parietal bones, and distraction devices were placed. The bone flaps were moved laterally to the scheduled distance.

（MCDO）法が開発されている ${ }^{42)}$.

\section{課 題}

これまで述べたように新しい手術法は進化してきてい るが, 手術により知能予後は改善するか, 最適の手術年 齢はいつか, 軽症三角頭蓋に手術適応はあるか, 遺伝子 変異型 (genotype) と表現型（phenotype）の不一致な ぞ, 今後, 解決されるべき課題がある.

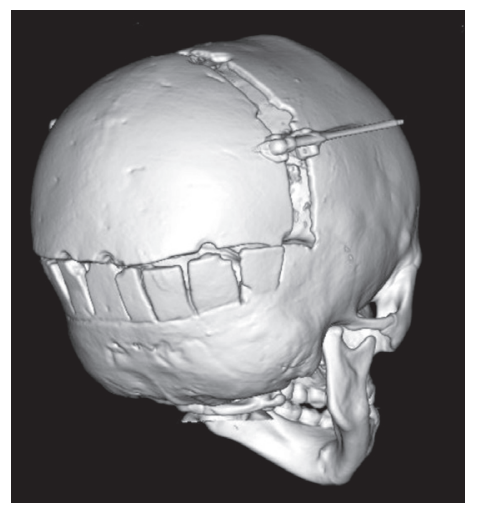

Fig. 4 Occipital expansion

The parieto-occipital bone flap was isolated. Barrel-shaped osteotomy was performed on the occipital bone, and the bone flap was outfractured.

\section{1 知能予後}

手術が知能予後を改善させるかどうかについてエビデ ンスレベルの高い報告はない7)。頭蓋内圧方進が続くと 発達遅滞や視力低下の原因となるので, 手術は, 予後を 改善させるよりも発達が悪化することを妨げる効果が強 いとする報告がある(34)8)。一方，手術により整容面は改 善するが認知機能改善効果はないとする報告もあ $3^{6(9) 25) 39(40)}$. 手術により頭蓋内圧を下げても知能予後が 改善しない理由として, 本疾患の背景に, 染色体異常や 遺伝子変異があり，合併先天異常が多いことが考えられ る。自験例の検討では, 症候群性頭蓋骨縫合早期癒合症 
では，66.7\%に発達遅滞があり，手術後改善した症例は ない. 一方, 非症候群性頭蓋骨縫合早期癒合症 41 例の $41.5 \%$ に発達遅滞があり, 手術後に 2 例で運動機能が改 善し，1例で言語機能が改善した。しかし，それが手術 効果なのか, 児の発達によるものか判断は難しい（Table 2)。これに対し, 短頭蓋動物モデルにおいて, 早期に手 術を行うことで白質線維の変性を防ぐことができたとい う報告があり ${ }^{5)}$, 早期手術が認知機能低下を防ぐことが できることを示唆している.

\section{2 手術タイミング}

早期手術は, 前述のように認知機能発達を期待でき る, 視機能低下を阻止できる, 術後の骨形成が良好で骨 欠損ができにくい，といった利点がある。しかし，晚期 手術に比べ再手術が必要となることが多い ${ }^{47)}$. また, 縫

Table 1 Advantages and disadvantages of conventional cranioplasty and distraction osteogenesis

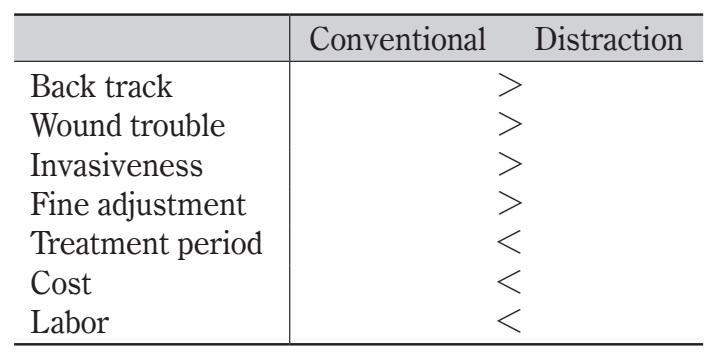

Table 2 Psycho-motor delay

\begin{tabular}{l|c|c}
\hline & Delay (cases) & $\begin{array}{c}\text { Postoperative } \\
\text { improvement }\end{array}$ \\
\hline Syndromic (15) & $10(66.7 \%)$ & 0 \\
Non-syndromic (41) & $17(41.5 \%)$ & 3 \\
\hline
\end{tabular}

Psycho-motor delay was found in 10 out of 15 syndromic children and 17 out of 41 non-syndromic children. Only three non-syndromic children showed postoperative improvement, but this may have been due to normal development.
合切除では，早期に手術を行わないと良好な形態を得ら れにくい（Table 3).

早期に手術を行うには，早期に診断することが必要だ が, 日本は欧米諸国に比べ診断, 手術時期が遅い. 過去 30 年の自験例の検討では, 診断年齢は早くなりつつある がまだ十分ではない (Table 4)。症候群, 非症候群とも多 くの症例は小児科でみつかっており，小児科医の本疾患 に対する認識が重要である（Fig.5)。しかしながら，乳 児健診の際に親が児の頭蓋形態について尋ねても、「経 過をみましょう」,「心配ありません」と言われ，専門医 受診が遅れることがある。近年，あたまの形外来が開設 されるようになり，本邦においても診断年齢が早くなる ことが期待される。

\section{3 軽症三角頭蓋}

軽症三角頭蓋の定義は明確ではないが, 通常, 眼窩変 形がなく前頭縫合が隆起として触知されるだけの頭蓋形 態（metopic ridge）を指す. Metopic ridge だけなのか, 前額部の狭小があり前頭葉を圧迫しているかの判断は難 しい. 軽症三角頭蓋は, 脳形成不全, 低酸素脳症後の脳 萎縮，水頭症に対するシャント術後にも起こる，本例の 手術適応については議論がある。軽症三角頭蓋でも手術 により前頭葉の圧迫を解除することで発達の改善が得ら れるとする報告がある ${ }^{35} 36$ ). 一方, 軽症三角頭蓋でも頭 蓋内圧充進があるとする手術適応判断や術後発達検査手 法に問題があり, この群に手術適応はないとする意見が ある ${ }^{13) 15) 16)}$. 欧米では metopic ridgeに手術適応はないと しているところが多い. 手術適応判断のために, 術前に

Table 3 Advantages and disadvantages of early and late surgery

\begin{tabular}{l|c}
\hline & Early op Late op \\
\hline Expect cognitive development & \multicolumn{2}{|c}{$>$} \\
Prevent visual impairment & \multicolumn{2}{|c}{$<$} \\
Postoperative skull defect & yes no \\
Suturectomy & $>$ \\
Re-operation & \multicolumn{2}{|c}{$>$ n } \\
\hline
\end{tabular}

Table 4 Chronological change in age at diagnosis classification of among non-syndromic children

\begin{tabular}{l|c|c|c|c|c|c}
\hline & $1982-1989$ & $1990-1994$ & $1995-1999$ & $2000-2004$ & $2005-2009$ & $2010-2014$ \\
\hline No. of patients & 3 & 7 & 6 & 6 & 7 & 9 \\
Ave. age (m.o.) & 6.7 & 26.6 & 26.3 & 19.7 & 4.9 & 8.6 \\
\hline
\end{tabular}

The average age at diagnosis is getting younger recently. 


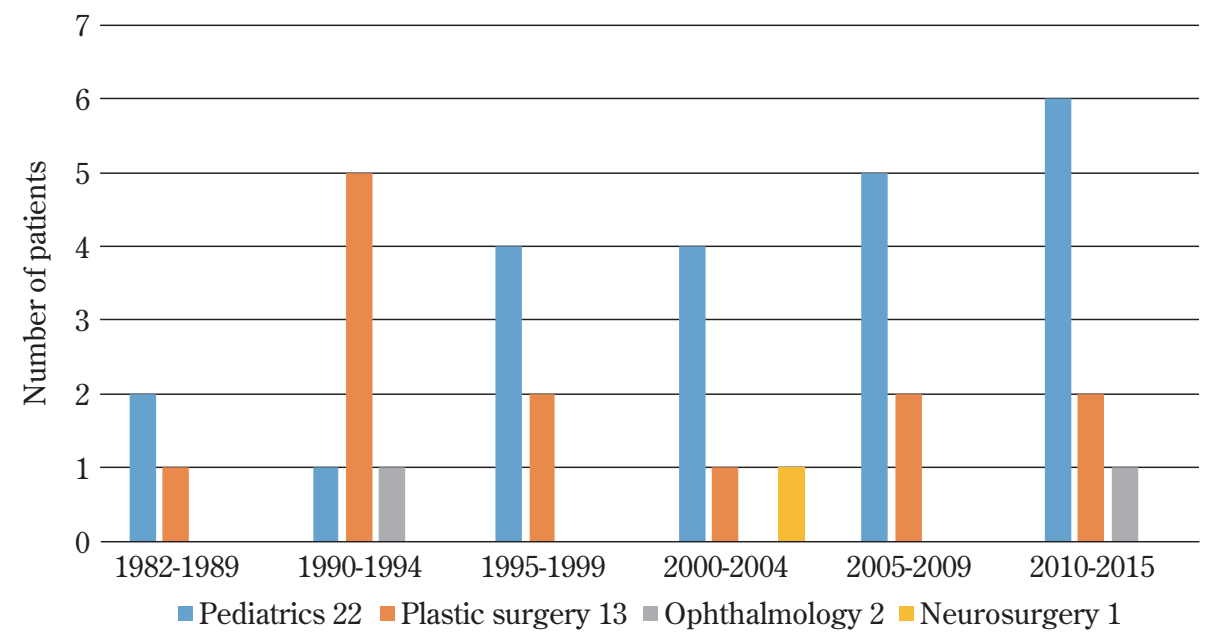

Fig. 5 Chronological change of departments noticed craniosynostosis among non-syndromic children

Increase in the number of patients diagnosed by pediatricians.

頭蓋内圧モニターが行われることがあるが，三角頭蓋の ような単縫合癒合で頭蓋内圧光進は少ないと報告されて

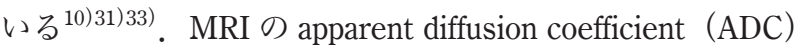
解析を利用して非侵襲的に頭蓋内圧を推測する手法が報 告された ${ }^{30) 43)}$ 。 今後，低侵襲で，信頼性の高い診断手技 が開発され，軽症三角頭蓋の手術適応判断に応用される ことを期待する。

\section{4 遺伝子変異}

各症例の遺伝子変異を検索し, 正確な診断を行うこと で，症例の予後を知ることが可能となる。これにより， 徵候の早期発見と対策および家族へのより正確な病状説 明が可能となる，特に，経験することがまれな症候群の 診断に遺伝子診断は有用である. 自験例でも，短頭蓋で 中顔面低形成の合併による眼球突出と呼吸不全があり, 手指異常のない症例において, 遺伝子診断で Beare-Stevenson cutis gyrata 症候群と診断することができた ${ }^{1)}$ 。こ れまでの検索では, 症候群では 15 例中 14 例 $(93.3 \%)$ に 遺伝子変異がみつかったが，非症候群 32 例に遺伝子変 異はみつからなかった。症候群性頭蓋骨縫合早期癒合症 全例に遺伝子変異を確認できるわけではないが32)，遺伝 子変異を確認できないと症候群と診断することは躊踷さ れる。これまでにみつかった遺伝子変異 (genotype) と 表現型（phenotype）は, 必ずしも一対一の対応がない. 自験例でも，同一の genotype であっても phenotype が Carpenterであったり Apertであったり，逆に Apert で あっても genotype が異なっていたり, Crouzonであって も genotype が異なっていた（Table 5)。これらょり， genotype だけで phenotype が決まるのではなく, 環境因
Table 5 Phenotype and genotype

\begin{tabular}{l|l}
\hline \multicolumn{1}{c|}{ Diagnosis } & \multicolumn{1}{c}{ Gene mutation } \\
\hline Carpenter & FGFR2 exon7 Ser252Trp \\
Apert & FGFR2 exon7 Ser252Trp \\
Apert & FGFR2 exon7 Pro253Arg \\
Crouzon (2) & FGFR2 exon7 Cys278Phe \\
Crouzon & FGFR2 exon9 Cys342Tyr \\
Crouzon & FGFR2 exon9 Cys342Ser \\
Pfeiffer & FGFR2 exon9 Cys342Arg \\
Unknown & FGFR2 exon9 Ser351Cys \\
B-S-C-G & FGFR2 exon10 Tyr375Cys \\
Muenke & FGFR3 exon7 Pro250Arg \\
Saethre-Chotzen (3) & TWIST1 Leu159Ile \\
\hline
\end{tabular}

FGFR : fibroblast growth factor receptor, $\mathrm{B}^{-} \mathrm{S}-\mathrm{C}-$ $\mathrm{G}$ : Beare-Stevenson- ${ }^{-}$cutis $^{-}$gyrata syndrome, $(2)$ : two patients, (3): three patients

子が関与している可能性が示唆される.

\section{治療戦略のアルゴリズム (Fig. 6)}

治療戦略は，まず，頭蓋内圧六進症状の有無で大きく 異なる，頭蓋内圧六進があるときは可及的早期の手術が 必要である。体重が $5 \mathrm{~kg}$ 未満のときは，舟状頭蓋であれ ば縫合切除後にヘルメットあるいは包帯により矯正す る。そのほかの頭蓋形態であれば基本的には従来法で骨 弁を作成して頭蓋形成を行う。縫合切除と molding helmet での治療も可能という報告もあるが長期成績の検討 が必要であろう 2021)．体重 $5 \mathrm{~kg}$ 以上であれば，後方拡大 を先行させる，その後，左右対象な変形である短頭蓋で は骨延長法で FOA を行い，斜頭蓋では，前頭骨や眼窩上 


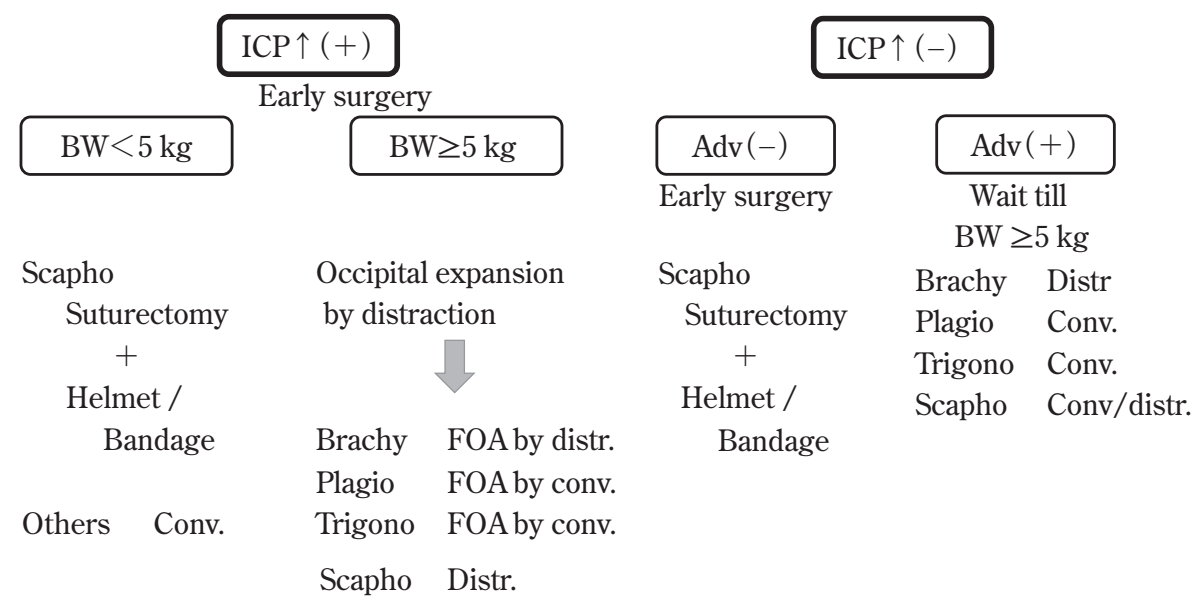

Fig. 6 Treatment algorithm

ICP : intracranial pressure, BW : body weight, Adv : need advancement, distr. : distraction, conv. : conventional, FOA : fronto-orbital advancement, Scapho : scaphocephaly, Brachy : brachycephaly, Plagio : plagiocephaly, Trigono : trigonocephaly

縁のカーブを作るために従来法で頭蓋形成を行う。三角 頭蓋では，蝶形骨縁を十分に削って前頭葉外側下面の圧 迫を取り除くため従来法で頭蓋形成を行うのが望ましい と考えている。舟状頭蓋は骨延長法，従来法いずれでも よい.

頭蓋内圧充進症状がない場合は, 頭蓋拡大が必要かど うかで判断する。舟状頭蓋では, 頭蓋拡大が不要である ので, 診断がつけば縫合切除後にヘルメットあるいは包 帯で形態を整える。手術は，骨が軟らかい 3 力月未満が 望ましい. 頭蓋拡大が必要なときは，移動した骨を保持 できるように児の体重が $5 \mathrm{~kg}$ を超えてから手術を行う. 短頭蓋, 斜頭蓋, 三角頭蓋, 舟状頭蓋における手術法は 前述の頭蓋内圧立進がある場合と同様である。

\section{今後の研究}

\section{1 頭蓋骨縫合早期癒合症日本版データベース作 成}

本疾患の発症率，頭蓋形態別頻度，症候群・非症候群 の頻度，各症候群の発症頻度などのデー夕は欧米のもの であり，本邦独自のデータはほとんどない。日本小児神 経外科学会が日本形成外科学会と協力して, 本邦の症例 を収集しデータベースを作成することを目指している。 それにより，発症頻度だけでなく，本疾患治療の現状が 明らかとなり，本邦における最適な術式，手術年齢，予 後解明へと発展することが期待される。

\section{2 頭蓋骨縫合早期癒合症発症予防に向けた研究}

頭蓋骨縫合早期癒合の原因となる骨形成関連の遺伝子 変異の解明が進んでいる2324)45)48)。また, fibroblast growth factor receptor(FGFR) ${ }^{37) 46)}, \mathrm{TGF}-\beta$ 抗体 ${ }^{12) 27) 28)}$, bone morphogenetic protein receptor inhibitor ${ }^{22)}$ な゙を局 所に導入することで早期癒合を防ぐ効果があることが報 告されている。一方，なぜ特定の縫合だけが早期癒合を 起こすのか不明である。骨だけでなく，罹患部骨膜，硬 膜の関与が示唆される。これらの解明により，本疾患の 発症予防へと進展することが期待される.

\section{結 語}

頭蓋骨縫合早期癒合症の手術法は，頭蓋形態や年齡に よって術式が異なる。また，その術式も新しい手術器具 の開発により変遷があり，今後もよりよい術式が開発さ れていくことが期待される。本疾患は, 術式とその時期, 手術適応，予後などいまだコンセンサスとなっていない ところが多く, 病態解明を含め, 今後の課題である.

\section{COI の開示}

著者のうち，山下昌信は，自己申告による COI 報告書を日 本脳神経外科コングレス事務局に提出しています。その他の 著者全員は，日本脳神経外科学会への COI 自己申告を完了し ています。いずれも本論文に関して開示すべき COI はありま せん.

\section{文 献}

1) Akai T, Iizuka H, Kishibe M, Kawakami S, Kobayashi A, 
Ozawa T: A case of Beare-Stevenson cutis gyrata syndrome confirmed by mutation analysis of the fibroblast growth factor receptor 2 gene. Pediatr Neurosurg $\quad 37: 97-$ 99, 2002.

2) Akai T, Iizuka H, Kawakami $\mathrm{S}$ : Treatment of craniosynostosis by distraction osteogenesis. Pediatr Neurosurg 42 : 288-292, 2006.

3) Arnaud E, Meneses P, Lajeunie E, Thorne JA, Marchac D, Renier D : Postoperative mental and morphological outcome for nonsyndromic brachycephaly. Plast Reconstr Surg 110: 6-12, 2002.

4) Bellew M, Chumas P, Mueller R, Liddington M, Russell J : Pre- and postoperative developmental attainment in sagittal synostosis. Arch Dis Child $90:$ 346-350, 2005.

5) Bonfield CM, Foley LM, Kundu S, Fellows-Mayle W, Hitchens TK, Rohde GK, Grandhi R, Mooney MP: The influence of surgical correction on white matter microstructural integrity in rabbits with familial coronal suture craniosynostosis. Neurosurg Focus 38 : E3, 2015.

6) Chieffo D, Tamburrini G, Massimi L, Di Giovanni S, Giansanti C, Caldarelli M, Di Rocco C : Long-term neuropsychological development in single-suture craniosynostosis treated early. J Neoursurg Pediatr $\quad \mathbf{5}: 232-237,2010$.

7) Chummun S, McLean NR, Flapper WJ, David DJ : The Management of Nonsyndromic, Isolated Sagittal Synostosis. $J$ Craniofac Surg $27:$ 299-304, 2016.

8) Cohen SR, Persing JA : Intracranial pressure in singlesuture craniosynostosis. Cleft Palate Craniofac J 35 : 194196, 1998.

9) Collett BR, Kapp-Simon KA, Wallace E, Cradock MM, Buono L, Speltz ML: Attention and executive function in children with and without single-suture craniosynostosis. Child Neuropsychol 23: 83-98, 2017.

10) Cornelissen MJ, Loudon SE, van Doorn FE, Muller RP, van Veelen MC, Mathijssen IM : Very Low Prevalence of Intracranial Hypertension in Trigonocephaly. Plast Reconstr Surg

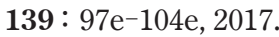

11) Dalle Ore CL, Dilip M, Brandel MG, Mclntyre JK, Hoshide R, Calayag M, Gosman AA, Cohen SR, Meltzer HS : Endoscopic surgery for nonsyndromic craniosynostosis : a $16^{-}$ year single-center experience. J Neurosurg Pediatr 22 : 335-343, 2018.

12) Frazier BC, Mooney MP, Losken HW, Barbano T, Moursi A, Siegel MI, Richtsmeier JT : Comparison of craniofacial phenotype in craniosynostotic rabbits treated with anti-Tgfbeta2 at suturectomy site. Cleft Palate Craniofac J 45 : 571-582, 2008.

13) Hicdonmez $\mathrm{T}$ : Children with Metopic Ridge. Turk Neurosurg 27: 585-589, 2017.

14) Hirabayashi S, Sugawara Y, Sakurai A, Harii K, Park S : Frontoorbital advancement by gradual distraction. Technical note. J Neurosurg 89: 1058-1061, 1998.

15) Ijichi S, Ijichi N, Ishida A, Yotsumoto M, Nagata J, Tanuma R, Imamura C, Toki A, Sakajiri T, Hirotsune H, Nakadoi Y, Tanaka S, Kimura K, Tanaka K : Ethical fallacies, tricky ambiguities, and the misinterpretation of the outcomes in the cranioplasty for mild trigonocephaly. Childs Nerv Syst 31: 1009-1012, 2015.

16) Ijichi S, Ijichi N, Sameshima H, Kawaike $Y$, Imamura $C$, Hazama K, Hirotsune H, Kimura K, Nakadoi Y, Oiji A, Ota J, Sakajiri T, Tanaka S, Tanaka K : A concise checklist to determine if the congnitive and/or behavioral changes are attributable to the effect of an intervention. Childs Nerv Syst 33 : 1429-1432, 2017.

17) Jimenez DF, Barone CM : Endoscopic craniectomy for early surgical correction of sagittal craniosynostosis. J Neurosurg 88: 77-81, 1998.

18) Jimenez DF, Barone CM, Cartwright CC, Baker L : Early management of craniosynostosis using endoscopic-assisted strip craniectomies and cranial orthotic molding therapy. Pediatrics 110 (1 Pt 1) : 97-104, 2002.

19) Jimenez DF, Barone CM : Endoscopic technique for coronal synostosis. Childs Nerv Syst 28: 1429-1432, 2012.

20) Jimenez DF, Barone CM : Early treatment of coronal synostosis with endoscopy-assisted craniectomy and postoperative cranial orthosis therapy : 16-year experience. J Neurosurg Pediatr 12:207-219, 2013.

21) Jimenez DF, McGinity MJ, Barone CM : Endoscopy-assisted early correction of single-suture metopic craniosynostosis : a 19-year experience. J Neurosurg Pediatr : 1-14, 2018. [Epub ahead of print]

22) Komatsu Y, Yu PB, Kamiya N, Pan H, Fukuda T, Scott GJ, Ray MK, Yamamura K, Mishina Y : Augmentation of Smaddependent BMP signaling in neural crest cells causes craniosynostosis in mice. J Bone Miner Res 28:1422-1433, 2013.

23) Kosty J, Vogel TW : Insights into the development of molecular therapies for craniosynostosis. Neurosurg Focus 38 : E2, 2015.

24) Lattanzi W, Barba M, Di Pietro L, Boyadjiev SA : Genetic advances in craniosynostosis. Am J Med Genet A 173 : 1406-1429, 2017.

25) Mathijssen I, Arnaud E, Lajeunie E, Marchac D, Renier D : Postoperative cognitive outcome for synostotic frontal plagiocephaly. J Neurosurg 105 (1 Suppl) : 16-20, 2006.

26) McCarthy JG, Schreiber J, Karp N, Thorne CH, Grayson $\mathrm{BH}$ : Lengthening the human mandible by gradual distraction. Plast Reconstr Surg $\mathbf{8 9 : 1 - 8 , 1 9 9 2 .}$

27) Mooney MP, Losken HW, Moursi AM, Bradley J, Azari K, Acarturk TO, Cooper GM, Thompson B, Opperman LA, Siegel MI : Anti-TGF-beta2 antibody therapy inhibits postoperative resynostosis in craniosynostotic rabbits. Plast Reconstr Surg 119: 1200-1212, 2007.

28) Mooney MP, Losken HW, Moursi AM, Shand JM, Cooper GM, Curry C, Ho L, Burrows AM, Stelnicki EJ, Losee JE, Opperman LA, Siegel MI : Postoperative anti-Tgf-beta2 antibody therapy improves intracranial volume and craniofacial growth in craniosynostotic rabbits. J Craniofac Surg 18: 336-346, 2007.

29) Nguyen DC, Farber SJ, Skolnick GB, Naidoo SD, Smyth MD, Kane AA, Patel KB, Woo AS: One hundred consecutive endoscopic repairs of sagittal craniosynostosis : an elevation in care. J Neurosurg Pediatr 20: 410-418, 2017.

30) Osawa T, Mase M, Miyati T, Kan H, Demura K, Kasai H, Hara M, Shibamoto Y, Yamada K : Delta-ADC (apparent diffusion coefficient) analysis in patients with idiopathic normal pressure hydrocephalus. Acta Neurochir Suppl 114: 197200, 2012.

31) Renier D, Lajeunie E, Arnaud E, Marchac D : Management of craniosynostosis. Childs Nerv Syst 16 : 645-658, 2000.

32) Roscioli T, Elakis G, Cox TC, Moon DJ, Venselaar H, Turner AM, Le T, Hackett E, Haan E, Colley A, Mowat D, Worgan L, Kirk EP, Sachdev R, Thompson E, Gabbett M, McGaughran J, Gibson K, Gattas M, Freckmann ML, Dixon 
J, Hoefsloot L, Field M, Hackett A, Kamien B, Edwards M, Adès LC, Collins FA, Wilson MJ, Savarirayan R, Tan TY, Amor DJ, McGillivray G, White SM, Glass IA, David DJ, Anderson PJ, Gianoutsos M, Buckley MF : Genotype and clinical care correlations in craniosynostosis: findings from a cohort of 630 Australian and New Zealand patients. Am J Med Genet C Semin Med Genet 163C : 259-70, 2013.

33) Ruane EJ, Garland CB, Camison L, Fenton RA, Nischal KK, Pollack IF, Tamber MS, Grunwaldt LJ, Losee JE, Goldstein JA : A Treatment Algorithm for Patients Presenting with Sagittal Craniosynostosis after the Age of 1 Year. Plast Reconstr Surg 140: 582-590, 2017.

34) Salokorpi N, Vuollo V, Sinikumpu JJ, Satanin L, Nestal Zibo H, Ylikontiola LP, Pirttiniemi P, Sándor GK, Serlo W : Increases in cranial volume with posterior cranial vault distraction in 31 consecutive cases. Neurosurgery $\mathbf{8 1}:$ 803-811, 2017.

35) Shimoji T, Tominaga D, Shimoji K, Miyajima M, Tasato K : Analysis of pre $^{-}$and post-operative symptoms of patients with mild trigonocephaly using several developmental and psychological tests. Childs Nerv Syst 31: 433-440, 2015.

36) Shimoji T, Kimura T, Shimoji K, Miyajima M : The metopicsagittal craniosynostosis - report of 35 operative cases. Childs Nerv Syst $33:$ 1335-1348, 2017.

37) Shukla V, Coumoul X, Wang RH, Kim HS, Deng CX : RNA interference and inhibition of MEK-ERK signaling prevent abnormal skeletal phenotypes in a mouse model of craniosynostosis. Nat Genet 39: 1145-1150, 2007.

38) Spruijt B, Rijken BF, den Ottelander BK, Joosten KF, Lequin MH, Loudon SE, van Veelen ML, Mathijssen IM : First vault expansion in Apert and Crouzon-Pfeiffer syndromes: Front or back? Plastr Reconstr Surg 137:112e-121e, 2016.

39) Starr JR, Kapp-Simon KA, Cloonan YK, Collett BR, Cradock MM, Buono L, Cunningham ML, Speltz ML : Presurgical and postsurgical assessment of the neurodevelopment of infants with single-suture craniosynostosis : comparison with controls. J Neurosurg $\mathbf{1 0 7}$ (2 Supple) : 103-110, 2007.

40) Starr JR, Collett BR, Gaither R, Kapp-Simon KA, Cradock
MM, Cunningham ML, Speltz ML : Multicenter study of neurodevelopment in 3-year-old children with and without single-suture craniosynostosis. Arch Pediatr Adolesc Med 166: 536-542, 2012.

41) Sugawara Y, Hirabayashi S, Sakurai A, Harii K : Gradual cranial vault expansion for the treatment of craniofacial synostosis : a preliminary report. Ann Plast Surg $\quad 40: 544-565$, 1998.

42）菅原康志，辻 直子，須永 中，野村紘史，香川広司， 宇田宏一, 去川俊二, 平林慎一: Multi-directional cranial distraction osteogenesis（MCDO）システムによる頭蓋縫 合早期癒合症の治療. 形成外科 48:1017-1025, 2005.

43) Takahashi Y, Hori M, Shimoji K, Miyajima M, Akiyama O, Arai $\mathrm{H}$, Aoki S: Changes in delta ADC reflect intracranial pressure changes in craniosynostosis. Acta Radiol Open 6 : 2058460117728535. doi : 10.1177/2058460117728535. eCollection 2017.

44) Tessier P : Relationship of craniosynostosis to craniofacial dysostosis and to faciostenosis: a study with therapeutic implications. Plast Reconstr Surg $\quad 48: 224-237,1971$.

45) Twigg SR, Wilkie AO : A Genetic-Pathophysiological Framework for Craniosynostosis. Am J Hum Genet $97: 359-377$, 2015.

46) Yokota M, Kobayashi Y, Morita J, Suzuki H, Hashimoto Y, Sasaki Y, Akiyoshi K, Moriyama K : Therapeutic effect of nanogel-based delivery of soluble FGFR2 with S252W mutation on craniosynostosis. PLoS One 9: e101693, 2014.

47) Wagner JD, Cohen SR, Maher H, Dauser RC, Newman $\mathrm{MH}$ : Critical analysis of results of craniofacial surgery for nonsyndromic bicoronal synostosis. J Craniofac Surg 6 : 32-37, 1995.

48) Wilkie AO, Bochukova EG, Hansen RM, Taylor IB, RannanEliya SV, Byren JC, Wall SA, Ramos L, Venâncio M, Hurst JA, O'rourke AW, Williams LJ, Seller A, Lester T : Clinical dividends from the molecular genetic diagnosis of craniosynostosis. Am J Med Genet A 143 A : 1941-1949, 2007.

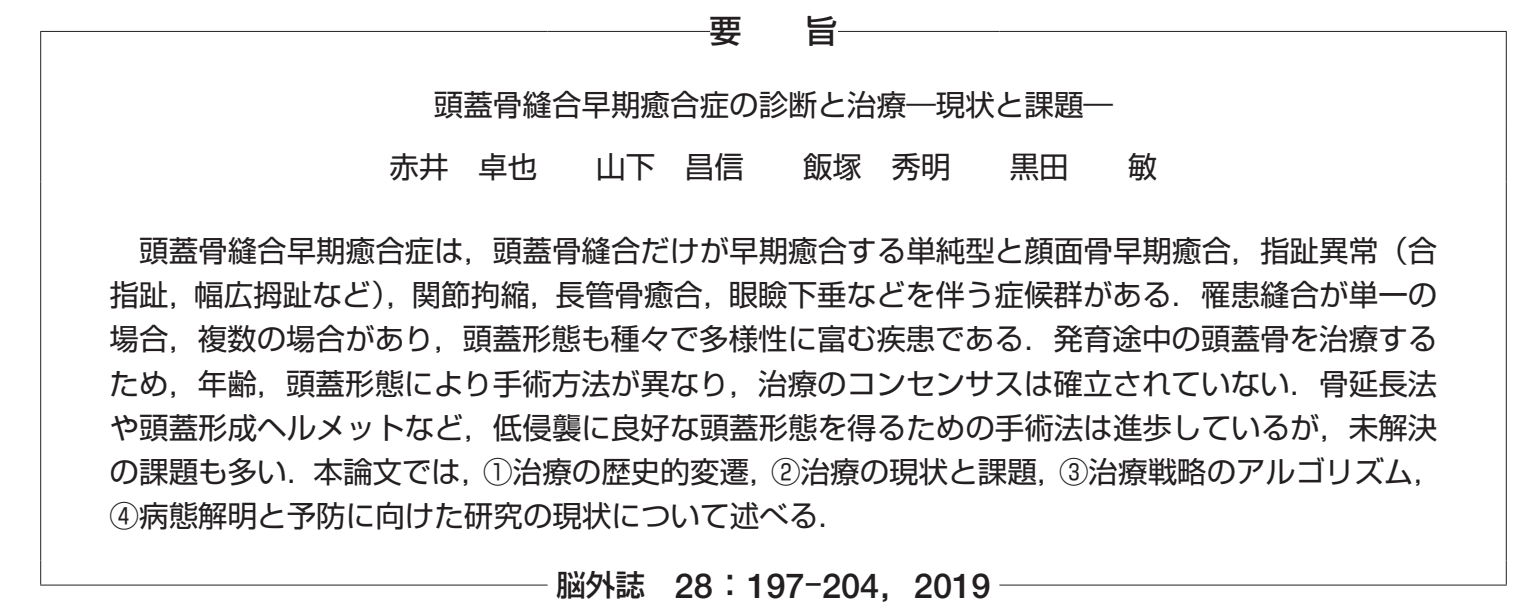

